\title{
Correction to: COVID-19 and air pollution in Vienna-a time series approach
}

\author{
Hanns Moshammer - Michael Poteser · Hans-Peter Hutter
}

Published online: 17 June 2021

(c) The Author(s) 2021

\section{Correction to:}

Wien Klin Wochenschr 2021

https://doi.org/10.1007/s00508-021-01881-4

The original version of this article unfortunately contained a mistake in Fig. 2. The correct figure can be found below. The authors apologize for the mistake. The original article has been corrected.

The online version of the original article can be found under https://doi.org/10.1007/s00508-021-01881-4.

\section{H. Moshammer $(\bowtie) \cdot$ M. Poteser $\cdot$ H.-P. Hutter} Department of Environmental Health, Center for Public Health, Medical University Vienna, Kinderspitalgasse 15, 1090 Vienna, Austria hanns.moshammer@meduniwien.ac.at

\section{Poteser}

michael.poteser@meduniwien.ac.at

\section{H.-P. Hutter}

hans-peter.hutter@meduniwien.ac.at

\section{H. Moshammer}

Department of Hygiene, Medical University of

Karakalpakstan, 230100 Nukus, Uzbekistan
Funding Open access funding provided by Medical University of Vienna.

Open Access This article is licensed under a Creative Commons Attribution 4.0 International License, which permits use, sharing, adaptation, distribution and reproduction in any medium or format, as long as you give appropriate credit to the original author(s) and the source, provide a link to the Creative Commons licence, and indicate if changes were made. The images or other third party material in this article are included in the article's Creative Commons licence, unless indicated otherwise in a credit line to the material. If material is not included in the article's Creative Commons licence and your intended use is not permitted by statutory regulation or exceeds the permitted use, you will need to obtain permission directly from the copyright holder. To view a copy of this licence, visit http://creativecommons.org/licenses/by/4.0/.

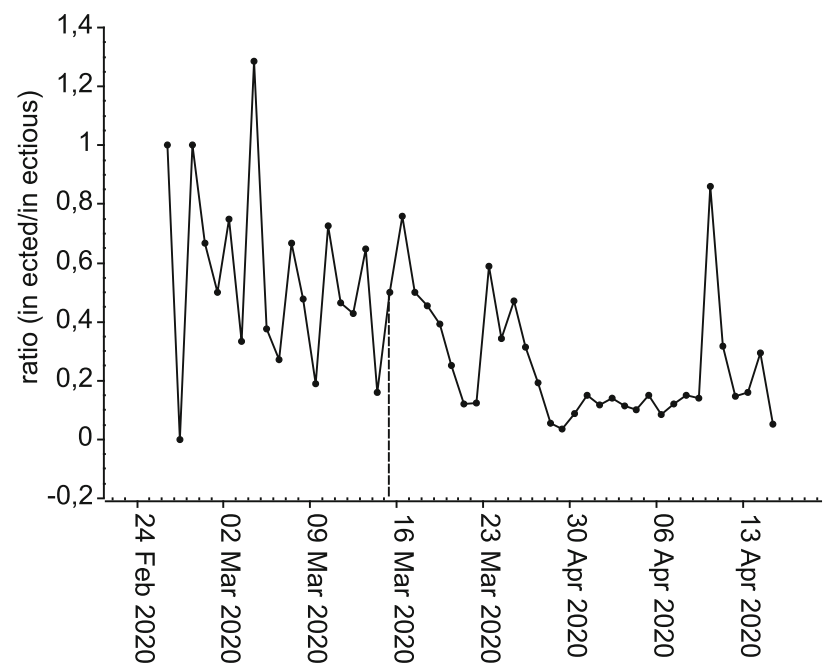

Fig. 2 Time course of the estimated ratio of infected by infectious persons in Vienna (23 February 2020 - 21 April 2020) assuming 6 infectious days in total beginning 1 day before diagnosis (March 16th, the onset of measures, marked by a dashed line) 